\title{
Entrepreneurship Development Program Through Gontor Agrotech Training Centre In University of Darussalam Gontor
}

\author{
Alfu Laila \\ Department of Agrotechnology University of Darussalam Gontor \\ Ponorogo, Indonesia \\ alfulaila@unida.gontor.ac.id \\ Niken Trisnnaningrum \\ Department of Agrotechnology University of Darussalam Gontor \\ Ponorogo, Indonesia \\ nikentrisnaningrum@unida.gontor.ac.id
}

\begin{abstract}
Nowadays, many universities around the world are in the process of strengthening their entrepreneurship education programs in order to create more young entrepreneurs in the future. University of Darussalam Gontor provided the requirement through Gontor Agrotech Training Centre with entrepreneurship in Agriculture as a core. The aims of the program are 1) producing students and graduates from University of Darussalam Gontor with entrepreneurial mindset; 2) increasing the number of young entrepreneurships in Agriculture. To achieve the objectives, the training created three strategic levels which were 1) selection and recruitment; 2) mentoring; and 3) monitoring and evaluation. The results of the program were 1) 23 students were selected from varied study programs, 2) 8 starts up business in Agriculture.
\end{abstract}

Keywords-Agriculture, entrepreneurship, young

\section{INTRODUCTION}

According to Central Bureau of Statistics, number of unemployment graduates from university level increasing every year [1]. It caused by most of the education in Indonesia prepare their students to be labourer. In fact, job market is not equal to job seeker. Recently, development of entrepreneurship has become crucial factors for a sustainable economic and social development around the world [2]. Government-supported programs has become an important part of development for small and medium enterprises in Indonesia [3] [4].

Rural areas of Indonesia are mostly dominated by agricultural sector. In contrast, the youth generation resource is crisis in agricultural sectors [5]. Entrepreneurship in Agriculture is necessary to develop for youngsters [6] [7]. One of the solve the problem is through social empowerment. The empowerment is not only can be done by increasing the capacity of physical resources for agricultural practice, but also non-physical resource capacity for example capacity management, social capital, entrepreneurship, and the relationship between business sectors [8].

Many universities are the process of their entrepreneurship building through education program in class [9]. Unfortunately, the result is less producing youth entrepreneur. University of Darussalam Gontor provided to strengthening entrepreneurship education program through Gontor Agrotech Training Centre with entrepreneurship in

\author{
Lutfy Ditya Cahyanti \\ Department of Agrotechnology University of Darussalam Gontor \\ Ponorogo, Indonesia \\ lutfyditya@unida.gontor.ac.id \\ Use Etica \\ Department of Agrotechnology University of Darussalam Gontor \\ Ponorogo, Indonesia \\ alfulaila@unida.gontor.ac.id
}

Agriculture as a core. The aims of the program were 1) producing 20 students and graduates from University of Darussalam Gontor with entrepreneurial mindset; 2) release 5 business units in Agriculture.

\section{METHODS}

Entrepreneurship development program through Gontor Agrotech Training Centre created three strategic levels which were 1) selection and recruitment; 2) mentoring; and 3) monitoring and evaluation.

\section{1) Selection and Recruitment}

The program is widely published. The candidates went through a three stages selection process, starting with a simple written application form, which is followed by send the outline of business plan. Those who pass these tests were then interviewed in order to assess what were known as 'entrepreneurial traits' such as achievement motivation, attitude to risk, initiative, optimism and self-confidence, their understanding and commitment to the training.

\section{2) Mentoring}

The mentoring is designed to help students start their own businesses through workshop of motivation, business plan mentoring, enterprise mentoring, and workshop of feasibility analysis of business.

\section{3) Monitoring and Evaluation}

Evaluation was conducted with focus group discussions and direct dialogue with the tenants on concerning the business development, activities and its management.

\section{RESULTS AND DISCUSSION}

\section{A. Results and Selection}

The program is widely published, and the 23 trainees were selected from various program of studies and semester (Table 1). They are from Department of Agrotechnology, Agroindustry, Informatic Engineering, International Relations, Comparative Studies, Management, Occupational Health and Safety, and Sharia Economic. The trainee ranged from 2 nd semester to 8 th semester. There was no trainee from graduates because the University was published at 2014 so no graduates in 2018 . The candidates were mostly 
having a strong commitment to become young entrepreneurs.

\section{B. Mentoring}

Mentoring started with a review of the needs required by students in developing and improving entrepreneurial competence in Agriculture. The mentoring programs consisted of four programs including workshop of motivation, business plant mentoring, enterprise activities mentoring, and workshop of feasibility business analysis (Table 2).

Workshop of motivation aimed to encouraging the entrepreneurial spirit. The workshop had as a theme young entrepreneur answers future graduate. All of trainee joined it. The program followed by business plan mentoring. The objective of business plan was creating proposal starts up business plan for developing young entrepreneurs from various departments.

Business plan mentoring resulted 8 starts up business based on science and technology application in five categories which were horticulture production, mushroom production, aquaculture, livestock and fishery (Table 3). In this program the trainee become tenant. Some of business unit has already worked independently such as intercropping chili and watermelon production and fresh juice "Fruida". Two groups carried out from creativity programs which were catfish production using Bioflock technology and palm sugar snacks production "Glorins". The others were new starts up business e.g. vegetable production with low inputs, mushroom production, poultry "kampung" chicken with organic animal feed, and catfish nugget without preservatives.

Table 1. Result of Tenant Recruitment of Gontor Agrotech Training Centre

\begin{tabular}{llcc}
\hline Tenant & Department & Semester & $\begin{array}{c}\text { Number of } \\
\text { Person }\end{array}$ \\
\hline Students & Agroindustry & 4.6 .8 & 3 \\
& Agrotechnology & 4.6 .8 & 9 \\
& Informatic Engineering & 4 & 1 \\
& International Relations & 8 & 2 \\
& Comparative Studies & 8 & 1 \\
& Management & 2.4 .6 & 4 \\
& Occupational Health and & 4 & 1 \\
\hline Safety & Sharia Economic & 4.6 & 2 \\
\hline Total of Students Number & & $\mathbf{2 3}$ \\
\hline $\begin{array}{l}\text { Alumni / } \\
\text { Graduates }\end{array}$ & & 0 \\
\hline Total of Alumni Number & $\mathbf{0}$ \\
\hline
\end{tabular}

In enterprise program, each two starts up business groups has a facilitator. The facilitator is responsible for each group has to spend some time for advance preparation in the area where it is to be held, identify promising business opportunities, improve the weakness of business unit and facilitate to collaborate with others. Also, a facilitator has to help the tenants how to prepare a feasibility business. Workshop of feasibility business analysis aimed to determine the viability of each business for evaluation periodically.

\section{Monitoring and Evaluation}

Evaluation was conducted with focus group discussions and direct dialogue with the tenants. Results of evaluation were strength, weakness, opportunities and threat each business unit. A facilitator would follow-up the results in enterprise activities mentoring program.

Table 2. Mentoring Programs of Gontor Agrotech Training Centre

\begin{tabular}{lll}
\hline No & Program & Target \\
\hline 1. & $\begin{array}{l}\text { Workshop of } \\
\text { motivation } \\
\text { Business plan } \\
\text { mentoring }\end{array}$ & $\begin{array}{l}\text { Encouraging the entrepreneurial spirit } \\
\text { Creating proposal starts up business plan } \\
\text { for developing young entrepreneurs from } \\
\text { various departments } \\
\text { Accelerate the growth of the enterprise }\end{array}$ \\
3. & $\begin{array}{l}\text { Enterprise } \\
\text { activities } \\
\text { mentoring }\end{array}$ & $\begin{array}{l}\text { Forum group } \\
\text { discussion }\end{array}$ \\
5. & $\begin{array}{l}\text { Workshop of } \\
\text { feasibility } \\
\text { business analysis }\end{array}$ & To determine the viability of their business \\
\hline
\end{tabular}

Table 3. Business Unit of Gontor Agrotech Training Centre

\begin{tabular}{|c|c|c|c|}
\hline No & Business Unit & Enterprise Status & Category \\
\hline 1 & Vegetable & New & Horticulture Production \\
\hline 2 & $\begin{array}{l}\text { Chili and } \\
\text { watermelon } \\
\text { Mushroom Al- }\end{array}$ & On going & Horticulture Production \\
\hline 3 & Gitza & New & Mushroom Production \\
\hline 4 & Bio flock & $\begin{array}{l}\text { Continue from } \\
\text { enterprise } \\
\text { creativity program }\end{array}$ & Aquaculture \\
\hline 5 & Chicken farm & New & Livestock \\
\hline 6 & $\begin{array}{l}\text { Glorins : Palm } \\
\text { Sugar }\end{array}$ & $\begin{array}{l}\text { Continue from } \\
\text { enterprise } \\
\text { creativity program }\end{array}$ & Agroindustry \\
\hline 7 & Fish Nugget & New & Agroindustry \\
\hline 8 & $\begin{array}{l}\text { Fruida (Fresh } \\
\text { Juice) }\end{array}$ & On going & Agroindustry \\
\hline
\end{tabular}

\section{CONCLUSION}

1) Twenty-three students were selected from varied study programs as tenants.

2) Eight business units in Agriculture are starting up.

\section{ACKNOWLEDGMENT}

This program was funded by Directorate for Higher Education, Ministry of the Education Republic of Indonesia through a grant to the Directorate for Research and Public Service. 


\section{REFERENCES}

[1] Central Statistics Agency. 2016. http://www.bps.go.id

[2] Hermanto and Suryanto. 2017. Entrepreneurship Ecosystem Policy in Indonesia. Mediterranean Journal of Social Sciences 8 (1) : $110-$ 115 .

[3] Mirzanti, I.R., Togar M.S., and Dwi L. 2014. Mapping on Entrepreneurship Policy in Indonesia. Procedia-Social and Behavioral Sciences 169:346 - 353 .

[4] Tambunan, T. 2007. Entrepreneurship Development: Smes in Indonesia. Journal of Developmental Entrepreneurship 12 (1): 95 118.

[5] Ridha, R.N., Burhanudin and Budi P. W. 2016. Entrepreneurshipintention in agricultural sectoe of youth generation in Indonesia. Asia Pacific Journal of Innovation and Entrepreneurship 11 (1) : 76 - 89.

[6] Mappigau, P., and Jusni. 2012. Entrepreneurial Quality of Smale Scale (SMEs) Broiler Farming with Independent Business Model in Maros District of South Sulawesi Provincy, Indonesia. International Journal of Business and Social Science 3 (6) : $74-81$.

[7] Hasan, B., Hasbullah, W. Purnama, and A. Hery. 2016. Entrepreneurial modelbased technology creative industries sector software through the use of free open source software for Universitas Pendidikan Indonesia students. International Conference on Innovation in Engineering and Vocational Education. IOP Conf. Series: Materials Science and Engineering $128: 1-7$.

[8] Kurniati, E.D. 2015. Entrepreneurial Empowerment of Agriculture and Industrial Sector in Rural Areas of Semarang Regency Indonesia.

[9] Priyanto, S.H. 2012. Entrepreneurial and vocational learning in entrepreneurship education: Indonesian Non formal education perspective.

[10] Basic Research Journal of Business Management and Accounts 1(2) : 30-36. 